\title{
Infantile Haemangiomas: A Review on Treatment Modalities
}

\author{
Hira Burhan*, Syed Murtaza Hasan Kazmi, Noman Lateef, Abdul Basit Ansari, Mudassir Shah
}

Dow University of Health Sciences, Karachi

*Corresponding author: Hira Burhan, MD, Dow University of Health Sciences, Karachi, Pakistan;

E-mail: hira.burhan91@gmail.com

\begin{abstract}
Background: Infantile haemangioma is the most common benign vascular tumor in children. They are more common in females and in infants born prematurely. Haemangiomas are mostly found on the head and neck regions $(60 \%)$, and are classified according to their depth. Most common complication is ulceration which affects nearly $15-25 \%$ of patients. Diagnosis is mainly based on history and physical examination but a colour Doppler ultrasonography along with an MRI can be further performed.

Conclusion: While most of the haemangiomas do not require any medical or surgical treatment, those who do, can be treated with laser therapy, surgical therapy or drug therapy with the latter mostly used to reduce morbidity, mortality and to treat complications.
\end{abstract}

Keywords: Hemangiomas; Capillaries; Lasers
Received Date: July 11, 2017

Accepted Date: August 07, 2017

Published Date: August 10, 2017

Citation: Burhan, H., et al. Infantile Haemangiomas: A Review on Treatment Modalities. (2017) Int J Hematol Ther 3(3): $1-5$.

DOI: $10.15436 / 2381-1404.17 .1599$

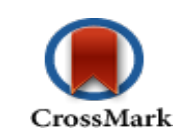

\section{Background}

Infantile haemangioma is the most common benign vascular tumour-affecting children and are composed of proliferating endothelial tumor cells, and usually manifest as cutaneous birthmarks ${ }^{[1]}$. They occur 4 times more frequently in females than males, and are especially common among premature births ${ }^{[2]}$. Approximately half of haemangioma are present at birth; the remainder become evident within the first month of $\operatorname{life}^{[3]}$.

The natural course of hemangiomas is divided into: rapid proliferating phase $(0-1 \mathrm{yr})$, involuting phase $(1-5 \mathrm{yr})$ and the involuted phase $(5-10 \mathrm{yr})^{[4]}$. Though they can occur in almost all regions of the body, they can be found more commonly in the head and neck $(60 \%)$, followed by the trunk $(25 \%)$ and then the extremities (15\%). Superficial hemangiomas are located in the papillary dermis, where as the deep-seated haemangiomas extend deep into the reticular dermis or subcutaneous tissue. Compound haemangiomas exhibit both, superficial and deep characterstics ${ }^{[5]}$.
The most common complication of a haemangioma, occurring in $15-25 \%$ of the patients is ulceration. Patients aged between 4 to 6 months are at the highest risk of acquiring this complication ${ }^{[6]}$. The appearance of gray-white colour on the surface of a haemangioma indicates the development of an ul$\operatorname{cer}^{[7]}$. Ulceration results in scarring along with significant pain and functional impairment, e.g. difficulty moving an affected limb and periocular haemangioma causing astigmatism due to its mass effect on the cornea. Such functional impairment can further lead to amblyopia and a permanent vision loss. Bleeding occurs in $40 \%$ of ulcerations ${ }^{[6]}$. Another complication is the involvement of vital structures, for example, the liver, can result in high output congestive heart failure ${ }^{[8]}$. Up to $30 \%$ of patients with large, facial segmental haemangiomas have PHACE (posterior fossa malformations, arterial anomalies, cardiac anomalies, eye abnormalities and sternal/supraumbilical raphe) and the most common extracutaneous findings are arterial anomalies of the cerebral vasculature and coarctation of the aorta ${ }^{[9]}$. Table 1 


\begin{tabular}{|c|c|c|c|c|c|}
\hline \multicolumn{6}{|c|}{ TREATMENT MODALITIES } \\
\hline & $\begin{array}{l}\text { WORKING } \\
\text { PRINCIPLE }\end{array}$ & INDICATIONS & TYPES & USE AND ADVANTAGE & DISADVANTAGES \\
\hline \multirow[t]{3}{*}{$\begin{array}{l}\text { LASER } \\
\text { THERAPY }\end{array}$} & \multirow{3}{*}{$\begin{array}{l}\text { Acts on } \\
\text { intravascular } \\
\text { Oxyhaemoglobin } \\
\text { resulting in } \\
\text { Vascular injury }\end{array}$} & \multirow{3}{*}{$\begin{array}{l}\text { Early or } \\
\text { Superficial } \\
\text { haemangioma } \\
\text { (particularly oral } \\
\text { lesions) }\end{array}$} & $\begin{array}{l}\text {-Flash lamp- } \\
\text { plumped pulsed } \\
\text { laser }\end{array}$ & $\begin{array}{l}\text { Used for superficial haemagi- } \\
\text { omas and promotes regression } \\
\text { of involutinghaemangiomas } \\
\text { Good efficacy }\end{array}$ & $\begin{array}{l}\text { atrophic scars, ulcer- } \\
\text { ations, postoperative } \\
\text { purpura and transient } \\
\text { hyperpigmentation }\end{array}$ \\
\hline & & & -Nd:YAG laser & $\begin{array}{l}\text { Used for Haemangiomas with } \\
\text { subcutaneous component, } \\
\text { particularly effective for larger } \\
\text { and deep haemangiomas }\end{array}$ & Painful \\
\hline & & & -Argon laser & Used for vascular birthmarks & Hypertrophic scars \\
\hline \multirow[t]{4}{*}{ DRUG THERAPY } & \multirow{4}{*}{$\begin{array}{l}\text { Aim is to reduce } \\
\text { morbidity and } \\
\text { mortality } \\
\text { Mechanism of } \\
\text { action depends on } \\
\text { the type of drug } \\
\text { used }\end{array}$} & \multirow{4}{*}{$\begin{array}{l}\text { Multiple } \\
\text { haemangiomas, } \\
\text { rapidly } \\
\text { proliferative } \\
\text { haemangiomas, } \\
\text { and } \\
\text { haemangiomas } \\
\text { that are affecting } \\
\text { vital organs or } \\
\text { life threatening }\end{array}$} & $\begin{array}{l}\text {-Propanolol and } \\
\text { Topical Timolol }\end{array}$ & $\begin{array}{l}\text { First line therapy for prolifer- } \\
\text { ative and involutivehaeman- } \\
\text { giomas } \\
\text { Preferred for Severe or disfig- } \\
\text { uring haemangiomas }\end{array}$ & $\begin{array}{l}\text { Transient bradycar- } \\
\text { dia, hypotension } \\
\text { and gastrointestinal } \\
\text { discomfort }\end{array}$ \\
\hline & & & $\begin{array}{l}\text {-Oral and intrale- } \\
\text { sional corticoste- } \\
\text { roids }\end{array}$ & $\begin{array}{l}\text { Reserved for propranolol } \\
\text { resistant cases } \\
\text { Intralesional injection for } \\
\text { involuting phase haemangio- } \\
\text { ma with poor response to oral } \\
\text { drug or laser therapy }\end{array}$ & $\begin{array}{l}\text { Cushingoid face, dis- } \\
\text { turbance of growth, } \\
\text { and susceptibility to } \\
\text { serious infections }\end{array}$ \\
\hline & & & -IFN-alpha & $\begin{array}{l}\text { Used for rapidly growing, } \\
\text { life-threatening haemangiomas } \\
\text { and steroid resistant lesions } \\
\text { Short course, reduced financial } \\
\text { cost, good tolerance with } \\
\text { intralesional use }\end{array}$ & $\begin{array}{l}\text { Influenza-like symp- } \\
\text { toms, Altered bowel } \\
\text { habits, Neutropenia, } \\
\text { Aminotransferasemia }\end{array}$ \\
\hline & & & -Imiquimod & $\begin{array}{l}\text { Used for Small and moder- } \\
\text { ate-sized lesions involving the } \\
\text { non-conspicuous regions } \\
\text { Ease of use, controllability, } \\
\text { safety, lack of local irritation. }\end{array}$ & \\
\hline Surgical Therapy & $\begin{array}{l}\text { Remove or re-con- } \\
\text { tour the residual } \\
\text { deformity, scar, hy- } \\
\text { pertrophied tissues, } \\
\text { hyperpigmentation, } \\
\text { or fibrofatty tissues } \\
\text { and to improve cos- } \\
\text { metics and function }\end{array}$ & $\begin{array}{l}\text { Proliferative } \\
\text { and Involutive } \\
\text { haemangiomas }\end{array}$ & - & $\begin{array}{l}\text { Used for Non-responsive } \\
\text { Proliferating haemangiomason } \\
\text { the tip of nose and lip } \\
\text { Haemangiomas in the eyelids } \\
\text { that impair sight; or occurring } \\
\text { on the forehead and scalp } \\
\text { Use of naturally expanded skin } \\
\text { aiding in primary closure }\end{array}$ & $\begin{array}{l}\text { Risk of haemorrhage } \\
\text { and damage to vital } \\
\text { structures }\end{array}$ \\
\hline
\end{tabular}

\section{Diagnosis}

Diagnosis is made on the basis of patient history and physical examination. The changes in size and colour of haemangiomas are observed with time, with color changing from bright red to dull purple, and finally in spotted pigment. Deep haemangiomas involving the deep dermis and subcutis, may be skin-colored to blue-violet nodules, depending upon the depth of invasion. It can usually be difficult to distinguish haemangiomas from venous or lymphatic malformations, but accurate diagnosis can be made through a detailed history ${ }^{[10]}$.

If diagnosis is still uncertain, a color Doppler ultrasonography and/or MRI may be used to aid in the diagnosis. Haemangiomas have an isointense or hypointense signal on T1 images and are enhanced on T2 imaging. A rich fibro-fatty infiltration is also demonstrated through high-intensity foci within the involuted tumor on T1 weighted imaging ${ }^{[11]}$.
Laboratory studies can also be useful to assess the possible markers of haemangioma proliferation and differentiation. These include Serum and urinary vascular endothelial growth factor (VEGF), Urinary beta-fibroblast growth factor and Urinary matrix metalloproteinases (MMPs) ${ }^{[12]}$.

\section{Treatment}

The treatment of IH depends on the following factors: type of haemangioma, stage of the lesion, location and extent, number and distribution of the lesion (segmental/non-segmental), associated systemic involvement, presence or absence of ulceration and psychosocial distress of the parents or child ${ }^{[1]}$. Small isolated or multiple skin lesions on the face found after birth should be treated as soon as possible. Proliferative haemangiomas; however should be treated step by step, including systematic drug therapy followed by laser therapy which is then followed by sclerotherapy. Deep or large haemangiomas can be 
managed by drug therapy combined with laser therapy. Involuting or small, stable hemangiomas in non-vital sites require a close observation. Surgical excision is taken for residual lesions, scar, hypertrophy, or pigmentation. The growth of the lesions should be observed, recorded and photographed in the follow-up period.

Rapidly growing heamangiomas and those associated with complications like haemorrhage, infection or ulceration and functional problems, and those involving the facial vital structures, e.g. eyelids, nose, lips, auricle etc should be treated immediately ${ }^{[5]}$.

Laser Therapy: Laser therapies treat haemangiomas by acting on intravascular oxyhaemoglobin, resulting in vascular injury. It is the recommended for early or superficial haemangiomas and not suitable for management of deep-seated haemangiomas. The advantage of laser therapy is the simplicity of use, which can be repeated at an interval of 2 to 4 weeks $^{[13]}$. The laser therapy is particularly effective and safe against the oral lesions, while minimizing injury to unaffected adjacent tissues and critical structures, it causes 30 - $95 \%$ lightening in the intraoral portwine stains, $90 \%$ in the hemangiomas and $70 \%$ in arteriovenous malformations ${ }^{[14]}$. There are several types of lasers available for management of haemangiomas, including argon laser, flash lamp pumped pulsed dye laser and Nd:YAG laser. The choice of laser therapy is based on the location, size, and depth of the lesions. The flash lamp pumped pulsed dye laser in particular has proven itself as treatment option for superficial haemangiomas, in numerous studies. In the treatment of haemangiomas with subcutaneous components, the Nd:YAG laser is the treatment of choice ${ }^{[15]}$.

Flash lamp-pumped pulsed dye laser destroys the blood vessels selectively while keeping the overlying skin intact. It is thus used to promote regression and inhibit endothelial cell proliferation of superficial hemangiomas, and can also accelerate the regression of involuting hemangiomas ${ }^{[16]}$. Immediately after radiation, the treated area turns off-white, with a surrounding erythematous flare, which resolves after 7 to 14 days. The treated areas can be smeared with panthenol ointment afterwards. The patients are followed up at 2 to 4 weeks interval, and a repeated treatment may be needed after the first session, often at a 4-week interval[17]. FPDL is the first choice for laser treatment of haemangioma with good efficacy and fewer side effects. Common side effects include atrophic scars, ulcerations, postoperative purpura and transient hyperpigmentation etc ${ }^{[18]}$.

$\mathrm{Nd}$ :YAG laser treatment is very painful and should be performed under local or general anaesthesia. There is no clear standard in the operating parameters for continuous Nd:YAG laser treatment of haemangiomas. Flat lesions are treated with short exposure time and low energy, while longer exposure time and higher energy are for thick lesions. One to four days after treatment, the lesion becomes swollen and will last 5 days. A blister, or sometimes a scab, may be present, but requires no incision as the crust of the lesions fall off and the wound heals within 2 to 4 weeks posttreatment. Treatment can be repeated at an interval of every 5 to 8 weeks ${ }^{[15]}$. Compared with argon laser and FPDL, Nd:YAG laser is more suitable for larger and deep haemangiomas ${ }^{[18]}$.

The argon laser is used to treat various vascular birthmarks. It is characterized by an unselective thermal destruction of blood vessels in contrast to FPDL, resulting in subsequent damage to the adjacent normal tissues resulting in scarring. About $40 \%$ of infantile haemangiomas may be accompanied by hypertrophic scars after argon laser treatment, hence limiting its use in clinical practice and the popularity of the argon laser has markedly declined over the past decade because of its associated limitations and the development of the PDL ${ }^{[15]}$. There are other laser treatments as well like the potassium titanyl phosphate (KTP) laser and $\mathrm{CO}_{2}$ lasers. The KTP laser is often used to treat large caliber vessels. There is less purpura, swelling, and pain associated with KTP laser irradiation, but clinical results are consistently superior with the PDL ${ }^{[13]}$.

\section{Drug Therapy}

Drug therapy for infantile haemangiomas aims to reduce morbidity and mortality and to prevent complications. It is indicated for multiple haemangiomas, rapidly proliferative haemangiomas, and haemangiomas that are affecting vital organs or life threatening. Several drugs including corticosteroids, beta adrenergic blocker, interferons, Imiquimod and etc are used as drug therapies for haemangiomas ${ }^{[19]}$.

Oral and intralesional corticosteroids: The mechanism of action has not been understood completely; however, corticosteroids have been shown to inhibit VEGF-A expression and subsequent proliferation in haemangioma stem cells in a murine haemangioma model hence slowing down the growth of proliferative haemangiomas ${ }^{[20]}$. With the increasing use of propranolol for problematic haemangiomas, corticosteroids are only reserved for propranolol resistant $\operatorname{cases}^{[19]}$. The initial oral dose of prednisone is $4 \mathrm{mg} / \mathrm{kg}$ per day for 7 days. If the tumors stop growing or become smaller, the same dose continues for 3 weeks. Conversely, the dose is increased to $5 \mathrm{mg} / \mathrm{kg}$ per day for 7 days, then is tapered down gradually and ceased after 4 to 8 weeks $^{[21]}$. Intralesional injection of corticosteroids is used in involuting phase haemangioma patients with poor response to oral drug therapy or laser therapy. The overall response rate of local administration is $94.5 \%$ with the advantage of fewer side effects as compared to systemic administration ${ }^{[22]}$.

The main side effects of corticosteroids therapy are the Cushingoid face, disturbance of growth, and susceptibility to serious infections.

Beta-adrenergic blockers: Beta-blockers, most specifically propranolol and more recently topical timolol, have been in use since mid 2008 for infants with severe or disfiguring haemangiomas $^{[33]}$. Propranolol is a nonselective beta-blocker which can effectively control the proliferation of severe haemangioma and promote its regression not only during the proliferative phase but also, to a lesser extent, once growth has been completed. The possible mechanisms for treatment of infantile haemangiomas are unclear however some hypothesize that local vasoconstriction may be a factor, which is based on the early color change and softening of the lesion. One study has demonstrated that propranolol triggered apoptosis of capillary endothelial cells in adult rat lung tissue, suggesting a similar mechanism may be plausible for hemangioma endothelial cells ${ }^{[24]}$. The most important advantages of oral propranolol over glucocorticoids and anti-cancer drugs are efficacy and safety, with fewer side effects and low cost. The side effects include: transient bradycardia, hy- 
potension and gastrointestinal discomfort ${ }^{[25]}$. Propranolol has replaced corticosteroids as first-line therapy for both proliferative and involutive haemangioma. No protocol for initiating propranolol therapy and the duration of therapy in infants with haemangiomas is universally accepted. Discontinuation of propranolol results in rebound growth in patients. Therefore, many clinicians continue treatment until the growth phase is completed, which can be up to 1 year of age in deep or large infantile haemangio$\mathrm{ma}^{[26]}$. The suggested dosage is $2 \mathrm{mg} / \mathrm{kg}$ per day, divided into 2 to 3 doses; upto a duration of 6 - 8 months. Combined low-dose oral propranolol $1.5 \mathrm{mg} / \mathrm{kg} /$ day as first-line therapy and oral prednisolone $2 \mathrm{mg} / \mathrm{kg} /$ day might be useful in avoiding adverse effects of propranolol in young infants ${ }^{[27]}$.

Interferon alfa inhibits endothelial cell migration and proliferation and specific growth factors (eg, endothelial growth factor, fibroblast growth factor). Interferon- $\alpha$ is used to treat rapidly growing, life-threatening haemangiomas and lesions that are unresponsive to steroids ${ }^{[28]}$. Due to the potential severe adverse effects, its use is limited to patients with massive or life-threatening haemangiomas. The common complications include influenza-like symptoms, altered bowel habits as well as neutropenia and an increased level of aminotransferases. Although rare, neurotoxicity is remains main concern in the treatment of hemangiomas with interferon ${ }^{[29]}$. The usual dose of Interferon- $\alpha$ is 3 million $\mathrm{U} / \mathrm{m}^{2}$ given subcutaneously per day for more than 3 months. The response rate is varied between $80 \%$ and $90 \%$. If no clinical effect is noticed after 1 month of administration, interferon- $\alpha$ should be discontinued ${ }^{[30]}$. An intralesional injection of IFN- $\alpha$ is also available, given intratumorally once a day for the first week; then once a week for 7 weeks. The advantages intralesional injection of IFN- $\alpha$ include a short course, reduced financial cost, good tolerance by patients and no major complications $^{[31]}$.

Imiquimod It works via production of a variety of cytokines, including interferon- $\alpha$, IL- 6 and TNF- $\alpha$. The inhibiting tumor growth and anti-angiogenesis effect of IL-12 may also play an important role in the imiquimod-induced regression of hemangiomas ${ }^{[32]}$. The efficacy of $5 \%$ imiquimod cream for the treatment of infantile hemangiomas has been confirmed by many authors in recent years, especially for small and moderate-sized lesions involving the non-conspicuous regions. It is applied topically once every other day, up to 3 to 5 months. The cream provides advantages in terms of the ease of use, controllability, safety, and lack of local irritation.

\section{Other agents}

Anti-cancer drugs (cyclophosphamide and vincristine) have also been used for the treatment of haemangiomas, but high levels of toxicity limits their use. Platelet derived growth factor (PDGF) are often used for ulcerated hemangiomas that are uncontrolled using steroids or laser therapy ${ }^{[33]}$.

\section{Surgical therapy}

With the advent of non-surgical approaches, surgical excision of haemangiomas is no longer the first choice treatment. However, residual deformities after conservative, or laser therapy can be corrected surgically in the involuting phase usually after the age of 3.5 years. The aim of surgery is to remove or re-contour the residual deformity, scar, hypertrophied tissues, hyperpigmentation, or fibrofatty tissues and to improve cosmetics and function. The benefits of excision during late involution include a reduced risk of hemorrhage and a potentially smaller lesion because of the natural course. In addition, because involuted haemangiomas are composed primarily of fibrofatty tissue, complete removal of all tissue is unnecessary, while removing too much tissue could detract from proper contours ${ }^{[34]}$. Proliferating haemangiomas require surgical excisions if they are located in the tip of nose and lip that do not respond well to other treatments; or haemangiomas in the eyelids that impair sight; haemangiomas occurring on the forehead and scalp, and repeated bleeding from the haemangiomas. Surgical excision of proliferating haemangiomas is potentially hazardous because of the risk of haemorrhage and damage to vital structures associated with them (i.e., head, neck); therefore, only specially trained surgeons should perform this procedure. Certain benefits to early excision include saving a life or preserving vision and decreasing the negative psychosocial effects associated with a cosmetically disfiguring lesion during early childhood. Other benefits of early excision include the use of naturally expanded skin to aid in primary closure and the ability to use a relatively avascular tissue plane surrounding actively growing hemangiomas ${ }^{[34]}$. There is also a latest study which shows that infantile hemangiomas can be successfully treated with coil embolization in combination with corticosteroids, particularly patients with infantile hemangioma associated with Kasabach-Merittsyndrome (KMS) [35].

\section{Conclusion}

Infantile haemangiomas are common, and while most do not require treatment, a small minority do. It is recommended that the physicians should be familiar with the natural history, specific growth characteristics and potential complications associated with infantile haemangioma, including ulceration, risk of disfigurement, functional impairment and potential association with structural anomalies. Educating parents about the variable natural history, prognosis, risks, and benefits of potential treatments and possible complications is also essential.

Conflict of Interests: Authors declare no competing interests.

\section{References}

1. Yilmaz, L., Dangoisse, C., Semaille, P. Infantile hemangioma and propranolol: a therapeutic "revolution" Literature review. (2013) Rev Med Brux 34(6): 479-484.

Pubmed I Crossref I Others

2. Walker, D.M., Hebert, A.A. Topical therapies and medications in the pediatric patient. (2000) Pediatric Clinics 47(4): 867- 876.

Pubmed I Crossref I Others

3. Finn, M.C., Glowacki, J., Mulliken, J.B. Congenital vascular lesions: clinical application of a new classification. (1983) J Pediatr Surg 18(6): 894-900.

Pubmed I Crossref I Others

4. Tan, S.T., Velickovic, M., Ruger, B.M., et al. Cellular and extracellular markers of hemangioma, (2000) Plast Reconstr Surg 106(3): 529538.

Pubmed I Crossref I Others

5. Zheng, J.W., Zhang, L., Zhou, Q., et al. A practical guide to treatment of infantile hemangiomas of the head and neck. (2013) Int J Clin Exp Med 6(10): 851-860

Pubmed I Crossref I Others 
6. Chamlin, S.L., Haggstrom, A.N., Drolet, B.A., et al. Multicenter prospective study of ulcerated hemangiomas. (2007) J Pediatr 151(6): 684-689.

Pubmed I Crossref I Others

7. Sheilagh, M., Maguiness, M.D., William, Y., et al. Early White Discoloration of Infantile Hemangioma A Sign of Impending Ulceration. (2010) Arch Dermatol 146(11): 1235-1239.

Pubmed I Crossref I Others

8. Christison-Lagay, E.R., et al. Hepatic hemangiomas: subtype classification and development of a clinical practice algorithm and registry. (2007) J Pediatr Surg 42(1): 62-67.

Pubmed I Crossref I Others

9. Haggstrom, A.N., Garzon, M.C., Baselga, E. Risk for PHACE syndrome in infants with large facial hemangiomas. (2010) Pediatrics 126: e418-426

Pubmed I Crossref I Others

10. van Rijswijk, C.S., van der Linden, E., van der Woude, H.J., et al. Value of dynamic contrast-enhanced MR imaging in diagnosing and classifying peripheral vascular malformations. (2002) AJR Am J Roentgenol 178(5): 1181-1187.

Pubmed I Crossref I Others

11. Baker, L.L., Dillon, W.P., Hieshima, G.B., et al. Hemangiomas and vascular malformations of the head and neck: MR characterization. (1993) AJNR Am J Neuroradiol 14(2): 307-314.

Pubmed I Crossref I Others

12. Zhang, L., Lin, X., Wang, W., et al. Circulating level of vascular endothelial growth factor in differentiating hemangioma from vascular malformation patients. (2005) Plast Reconstr Surg 116(1): 200-204.

Pubmed I Crossref I Others

13. Tanzi, E.L., Lupton, J.R., Alster, T.S. Lasers in dermatology: four decades of progress. (2003) J Am Acad Dermatol 49(1): 1-31.

Pubmed I Crossref I Others

14. Frigerio, A., Tan, O.T. Laser applications for benign oral lesions. (2015) Lasers Surg Med 47(8): 643-650.

Pubmed I Crossref I Others

15. Al Buainian, H., Verhaeghe, E., Dierckxsens, L, et al. Early treatment of hemangiomas with lasers. A review. (2003) Dermatology 206(4): 370-373.

Pubmed I Crossref I Others

16. Stier, M.F., Glick, S.A., Hirsch, R.J. Laser treatment of pediatric vascular lesions: Port wine stains and hemangiomas. (2008) J Am Acad Dermatol 58(2): 261-285.

Pubmed I Crossref । Others

17. Witman, P.M., Wagner, A.M., Scherer, K., et al. Complications following pulsed dye laser treatment of superficial hemangiomas. (2006) Lasers Surg Med 38(2): 116-123.

Pubmed I Crossref I Others

18. Ulrich, H., Bäumler, W., Hohenleutner, U., et al. Neodymium-YAG Laser for hemangiomas and vascular malformations -- long term results. (2005) J Dtsch Dermatol Ges 3(6): 436-440.

Pubmed I Crossref I Others

19. Richard, J.A., William, D.J. Infantile Hemangioma Medication.

Pubmed I Crossref I Others

20. Greenberger, S., Boscolo, E., Adini, I., et al. Corticosteroid suppression of VEGF-A in infantile hemangioma-derived stem cells. (2010) N Engl J Med 362(11): 1005-1013.

Pubmed I Crossref I Others

21. Frieden, I.J., Haggstrom, A.N., Drolet, B.A., et al. Infantile hemangiomas: current knowledge, future directions. Proceedings of a research workshop on infantile hemangiomas. (2005) Pediatr Dermatol 22(5): 383-406.

Pubmed I Crossref I Others
22. Chantharatanapiboon, W. Intralesional corticosteroid therapy in hemangiomas: clinical outcome in 160 cases. (2008) J Med Assoc Thai 91(3): 90-96.

Pubmed I Crossref I Others

23. Pope, E., Chakkittakandiyil, A. Topical timolol gel for infantile hemangiomas: a pilot study. (2010) Arch Dermatol 146(5): 564-565.

Pubmed I Crossref I Others

24. Sommers, S.S.K., Smith, D.M. Beta blockade induces apoptosis in cultured capillary endothelial cells. (2002) In Vitro Cell Dev Biol Anim 38(5): 298-304.

Pubmed I Crossref I Others

25. Drolet, B.A., et al. Review Initiation and use of propranolol for infantile hemangioma: report of a consensus conference. (2013) Pediatrics 131(1): 128-140.

Pubmed I Crossref I Others

26. Bagazgoitia, L., Hernandez-Martin, A., Torrelo, A. Recurrence of infantile hemangiomas treated with propranolol. (2011) Pediatr Dermatol 28: 658-662.

Pubmed I Crossref I Others

27. Koay, A.C., Choo, M.M., Nathan, A.M., et al. Combined low-dose oral propranolol and oral prednisolone as first-line treatment in periocular infantile hemangiomas. (2011) J Ocul Pharmacol Ther 27(3): 309311.

Pubmed I Crossref I Others

28. Ricketts, R.R., Hatley, R.M., Corden, B.J., et al. Interferon-alpha-2a for the treatment of complex hemangiomas of infancy and childhood. (1994) Ann Surg 219(6): 605-612

Pubmed I Crossref I Others

29. Dubois, J., Hershon, L., Carmant, L., et al. Toxicity profile of interferon alfa- $2 \mathrm{~b}$ in children: A prospective evaluation. (1999) J Pediatr 135(6): 782-785.

Pubmed I Crossref I Others

30. Bauman, N.M., Burke, D.K., Smith, R.J. Treatment of massive or life-threatening hemangiomas with recombinant alpha (2a)-interferon. (1997) Otolaryngol Head Neck Surg 117(1): 99-110.

Pubmed I Crossref I Others

31. Kaselas, C., Tsikopoulos, G., Papouis, G., et al. Intralesional administration of interferon A for the management of severe haemangiomas. (2007) Pediatr Surg Int 23(3): 215-218.

Pubmed I Crossref I Others

32. Sunamura, M., et al. The antiangiogenesis effect of interleukin 12 during early growth of human pancreatic cancer in SCID mice. (2000) Pancreas 20(3): 227-233.

Pubmed I Crossref I Others

33. Sugarman, J.L., Mauro, T.M., Frieden, I.J. Treatment of an ulcerated hemangioma with recombinant platelet-derived growth factor. (2002) Arch Dermatol 138(3): 314-316.

Pubmed I Crossref I Others

34. Zheng, J.W., et al, Treatment guideline for hemangiomas and vascular malformations of the head and neck. (2010) Head Neck 32(8): 1088-1098.

Pubmed I Crossref I Others

35. Tezuka, M., Ohta, M., Ochi, F., et al. Successful treatment by coil embolization for infantile hemangioma with Kasabach-Meritt syndrome of newborn. (2015) Pediatr Int 57(4): 738-741.

Pubmed I Crossref I Others

36. Gomathy,S., Vamsi, K., Yenamandra, et al. The treatment of IH depends on the following factors: Type of hemangioma, stage of the lesion, location and extent, number and distribution of the lesion (segmental/non-segmental), associated systemic involvement, presence or absence of ulceration and psychosocial distress of the parents or child. (2014) J Cutan Aesthet Surg 7(2): 75-85.

Pubmed I Crossref । Others
Ommega Online Publisher

International Journal of Hematology \& Therapy

Short Title : Int J Hematol Ther
ISSN: 2381-1404

E-mail : hematology.therapy@ommegaonline.org

website: www.ommegaonline.org 